LAILA ABU-AHMED

Higher Studies of Israel

\title{
THE IMPACT OF WORKING IN A SCHOOL PROJECT ON STUDENTS' BEHAVIOR AND SELF-PERCEPTION
}

\begin{abstract}
Abu-Ahmed Laila, The Impact of Working in a School Project on Students' Behavior and Self-Perception [Wpływ pracy w szkolnym projekcie na zachowanie studentów], Studia Edukacyjne nr 50, 2018, Poznań 2018, p. 463-486. Adam Mickiewicz University Press. ISSN 1233-6688. DOI: 10.14746/ se.2018.50.31
\end{abstract}

This article describes a school intervention program that was initiated and developed by a small team in one of the schools in the city of Nazareth, Israel. The proposed program is intended to promote academic perseverance and thereby reduce dropout rates, providing youth at risk with a variety of personal and interpersonal skills that are important both for studies and for labor world. The findings showed that combining learning with work in the candle factory promoted attendance and reduced violent behavior in school.

Key words: dropping out, academic persistence, self-efficacy, hope for the future, sense of control

The expectations from the education system are high: to improve student achievements; to deal with emigration and segregation; reducing dropout rate and more. Teachers must integrate all these goals into their daily activities. Many of them aspire to serve as agents of change for their students, helping them to find their place in life and prepare them for an ever-changing future. Teachers who regularly improve their teaching strategies are also agents of change for themselves and for their peers.

This article describes a school intervention program that was initiated and developed by a small team in one of the schools in the city of Nazareth. The program is intended for students at risk of dropping out of school, and it aims to promote perseverance in school, development of knowledge and important skills needed for an integration into the changing world of employment. 
Some $50 \%$ of the students in the State of Israel do not graduate school with a matriculation certificate, ${ }^{1}$ and therefore they are not applying for further academic studies. Most of them do not even find themselves in the labor market because they have not been prepared in school to integrate into the labor and employment world. Due to this situation, it is important that every graduate of the education system be prepared to pursue an academic career and an employment career. There should not be any separation between these two tracks, to which the education system graduates are exposed to as soon as they graduate. Every graduate must also acquire, besides academic studies, knowledge and skills in the field of employment and labor that awaits them.

In many countries around the world, where the goal of preparation for work and employment is getting importance, the education system constructs tracks that combine the option to complete matriculation studies alongside a work experience as part of the graduate preparation process for the employment world and the syllabus. The model that combines academic studies and employment is known in the research literature as Work Based Learning or WBL. This approach is implemented in many countries around the world and is intended for youth at the ages of 15-17 years old who are at risk of dropping out, low grades, low motivation and low self-confidence. The goal behind using the business world is to provide youth at risk with a variety of personal and inter-personal skills, as well as an opportunity to acquire an education and a profession that will help them integrate into society.

The programs in this model create for the children learning environments that combine academic studies together with employment-oriented courses and actual work in an vocational project sponsored by the school or in cooperation with a third party.

In view of the above, and due to the fact that a large number of students in our school, Al-Zahara middle school, are defined as student at risk of dropping school due to their low grades, involvement in violent incidents and absenteeism, and out of a commitment to our community and preventing a situation where our students graduate middle school without a diploma that will allow them to complete 12 study years or be out of work, we developed at school an intervention program for the advancement of studies through work. As part of the program, a candle-manufacturing factory was built within the school, where students classified as "latent dropouts" work and manage it together with teacher staff from school.

\footnotetext{
${ }^{1}$ CBS, Society in Israel, Statistical Annual - Report No. 3, Israel 2015, p. 8.
} 
"Candle Factory" is not only a workplace but also a non-frontal learning environment that introduces students to an experiential and authentic learning, which is adapted for their level and needs. In addition to working in the factory, the students learn the core subjects: languages, mathematics and science. They also receive vocational training through workshops by "Ta' asiyeda" - an educational non-profit association that provides training for schools in order to bring education closer to the industry.

The factory gave the students a platform to experience success in a different field from the academic one, in which they endured failure. A successful experience in a different field of practice, in which the student has not yet experienced any failure, and in which he has the potential to succeed, may increase the student's self-efficacy and even motivate them to experience learning, according to the notion that "success leads to success". We also believe that we may even be able to bring back even a small percentage of the students who are in danger of dropping out of school and help them graduate school with a matriculation certificate. Even those who find it difficult to study and receive an average that will enable them to proceed to high school and finish 12 years of schooling will benefit because they will receive a suitable preparation for the work life that awaits them outside.

The candle factory has several goals: maximizing student's personal potential, eradicating violence, reducing dropout rate, increasing the sense of belonging to the school, imparting work skills and raising their motivation, self-image and self-efficacy. The students in the factory work in four departments: packaging design department, production department, marketing and advertising department, and sales department. In exchange for working at the factory, the school provides the students with school uniform, the necessary equipment for learning such as notebooks, books, schoolbags and stationery, it also provides them with pocket money, and in addition organizes birthday parties and trips on holidays and vacations.

This article presents a special program for middle school students who are in danger of dropping out during the transition from middle school to high school. Each year, the Ministry of Education sets specific goals and objectives, and schools are requested to establish intervention programs to realize these goals. The Ministry of Education encourages the various teams to initiate programs and even supports them in realizing and implementing these programs. After working for a whole year on the program, it is time to examine the changes experienced by the students participating in the program, and how it can be further developed. To this end, a study was conducted intended to examine whether the work at the candle factory reduced school dropout and increased the sense of self-efficacy among the 
workers in the factory, and also promoted their sense of control and hope for the future.

As things stand, the importance of the "candle factory" project is in the significant learning that takes place in it. In order to encourage students to remain within this framework, it is important that a meaningful learning take place in it. $^{2}$ The student should feel that he is in the right place and that there is a staff-there that believes in him and in his ability to succeed. ${ }^{3}$

What distinguishes our intervention plan is that it was initiated and implemented by the school staff. We believe that student successes are also the successes of the staff, and that it is important to empower the staff no less than the students. Students can be reached through the teaching staff, because they are the ones who able to generate any change in school. The intervention program provided the teachers with the opportunity and platform to show their leadership and translate it into actual behaviors, and also gave the students a platform to show their leadership, depart out of the margins of society and find meaning to their lives.

\section{The research}

\section{Research questions and hypotheses}

1. Will a work in a school factory promote academic persistence, i.e., reduce dropout rates among students from a weak background?

Hypothesis 1: Integration of students from a weak background in a school factory will promote perseverance in learning, reduce tardiness, absenteeism and involvement in events of violence, that is, reduce latent dropout among students.

2. Will a work in a school factory improve the sense of self-efficacy of the students working in the factory?

Hypothesis 2: The sense of self-efficacy of the students working in the candle factory will be higher than that of their friends who do not work there.

3. What are the contributions of working in the candle factory to the students working in it?

Hypothesis 3: Working in the candle factory will contribute to the sense of control and hope for the future. The students working at the factory will report a greater contribution to their sense of control and hope for the future than students who do not work in the factory.

${ }^{2}$ M. Cohen-Navot, S. Ellenbogen-Frankovits, T. Reinfeld, Overt and Covert dropout among youth, JDC - Brookdale Institute 2001, p. 12-18.

${ }^{3}$ Ibidem. 


\section{Method}

The aim of the current study was to examine whether employing students from weak backgrounds in a school factory in order to provide them with employment and vocational training skills will affect the school dropout rate, their self-efficacy, optimism for the future and future orientation (hopes for and fears of the future).

The study is based on quantitative experimental field research as well as on data collection through questionnaires. Data is processed statistically in order to examine the research questions and enable generalizations and conclusions regarding the general population.

\section{Population}

Seventy (70) students, all under-achieving-teenagers 15 years old, who are at risk of dropping out of school participated in the study. All students are residents of the city of Nazareth, and are characterized by a low to moderate socioeconomic status, low scores and behavioral problems. All students that participated in the study live in culturally deprived neighborhoods and attend the same school, with half of them $(\mathrm{N}=35)$ working in the school factory (experimental group), and half $(\mathrm{N}=35)$ not working in it (control group).

\section{Procedure}

The experimental group includes 35 students who participate in the intervention program in a given school, in which they work in a school factory. This group was matched with a control group composed of students who attend the same school and are characterized by a similar socioeconomic profile and low achievements.

In addition to the information collected through the questionnaires, data was collected on tardiness, absenteeism and violent behaviors of the experimental group only, who is composed of students that work in the school factory. The data was collected at two points in time, at the end of school year preceding the initiation of the program and at the end of school year during which the students studied and worked within the framework of the school factory.

\section{Research tool}

The study employed three questionnaires: the new general self-efficacy(NGSE) questionnaire, a sense of control questionnaire, and a future hopes questionnaire. In addition, data were taken from the school database on the number of absences, tardiness, and involvement in events of violence for each of the research subjects employed at the school factory. 


\section{Findings}

\section{Absenteeism, tardiness and involvement in violent events}

Table 1 presents the distribution of the number of absenteeism, tardiness and involvement in violent events of students who took part in the school factory project during the year of initiating the project and the year before that.

Table 1 Ranges, averages and standard deviations of tardiness, absenteeism and involvement in violent events of subjects working in the factory at two points of time (before and after being integrated in the factory) $(n=35)$

\begin{tabular}{|l|l|c|c|c|}
\hline \multicolumn{1}{|c|}{ Measure } & Measurement time & Range & Average & $\begin{array}{c}\text { Standard } \\
\text { deviation }\end{array}$ \\
\hline \multirow{2}{*}{$\begin{array}{l}\text { Annual } \\
\text { tardiness }\end{array}$} & The preceding year & $9-28$ & 14.31 & 4.97 \\
\cline { 2 - 5 } & The project year & $4-10$ & 6.06 & 1.91 \\
\hline \multirow{2}{*}{$\begin{array}{l}\text { Annual } \\
\text { absenteeism }\end{array}$} & The preceding year & $6-15$ & 8.09 & 2.19 \\
\cline { 2 - 5 } $\begin{array}{l}\text { Annual } \\
\text { involvement in } \\
\text { violent events }\end{array}$ & The project year & $2-5$ & 3.00 & 0.87 \\
\cline { 2 - 5 } & The preceding year & $6-10$ & 7.40 & 1.19 \\
\hline
\end{tabular}

Looking of Table 1 we see that in the three dimensions (tardiness, absenteeism and involvement in violent events) there was a decrease in the period of working in the factory compared to the previous year. We can see that in the dimensions of absenteeism and involvement in violence there is no overlap between the annual ranges. Thus, for example, the number of absences during the year of working at the factory of the student with most absences ( $\max =5)$ was less than the those of the student with the smallest annual number of absences during the preceding year $(\mathrm{min}=6)$. These findings suggest a significant change in student habits. Another thing that can be observed is that the standard deviations decreased during the year. For example, the standard deviation of tardiness decreased from 4.97 to 1.91 . This tendency indicates that students with extreme values of tardiness, absenteeism, and violent incidents have been moderated so their behavior became more homogeneous.

The first hypothesis was that integrating students from a weak background into a school factory would promote their perseverance in learning, which in turn would reduce tardiness, absenteeism, and the extent of involvement in violent incidents. In order to examine this hypothesis, three t-tests were conducted for tardiness, absenteeism, and involvement in violent events, before and after the participation in the school factory project. The three tests stated that there are significant differences between the extent of tardiness $(t(34)=$ 
14.30, $\mathrm{p}<0.001)$, absenteeism $(\mathrm{t}(34)=14.30, \mathrm{p}<0.001)$ and involvement in violence $(\mathrm{t}(34)=14.30, \mathrm{p}<0.001)$ before and after the participation. The numbers of incidents of all three measurements decreased after the students have started to work in the factory. Based on this, we can say that the first research hypothesis was fully confirmed.

\section{Self-efficacy}

Table 2 presents the distribution of subjects' responses to statements regarding self-efficacy and the ability scale, by group (workers/non-workers in the factory).

Table 2

Percentages, averages and standard deviation of subjects responses to self-efficacy and ability scale statements, by group (workers/non-workers in the factory) $(\mathrm{N}=70)$

\begin{tabular}{|c|c|c|c|c|c|c|c|c|}
\hline $\begin{array}{l}\text { Statement/ } \\
\text { measure }\end{array}$ & Group & $\begin{array}{c}\text { To } \\
\text { a very } \\
\text { small } \\
\text { extent }\end{array}$ & $\begin{array}{l}\text { To } \\
\text { a small } \\
\text { extent }\end{array}$ & $\begin{array}{l}\text { To } \\
\text { a mo- } \\
\text { derate } \\
\text { extent }\end{array}$ & $\begin{array}{l}\text { To } \\
\text { a large } \\
\text { extent }\end{array}$ & $\begin{array}{l}\text { To } \\
\text { a very } \\
\text { large } \\
\text { extent }\end{array}$ & Average & $\begin{array}{l}\text { Stan- } \\
\text { dard } \\
\text { devia- } \\
\text { tion }\end{array}$ \\
\hline \multirow{2}{*}{$\begin{array}{l}\text { I can achieve } \\
\text { most goals } \\
\text { that I set for } \\
\text { myself }\end{array}$} & $\begin{array}{l}\text { Wor- } \\
\text { kers }\end{array}$ & & & $34 \%$ & $46 \%$ & $20 \%$ & 3.86 & 0.73 \\
\hline & $\begin{array}{l}\text { Non- } \\
\text {-wor- } \\
\text { kers }\end{array}$ & $3 \%$ & $37 \%$ & $27 \%$ & $3 \%$ & & 2.60 & 0.60 \\
\hline \multirow{2}{*}{$\begin{array}{l}\text { When I face } \\
\text { difficult tasks, } \\
\text { I am certain } \\
\text { that I will } \\
\text { complete } \\
\text { them }\end{array}$} & $\begin{array}{l}\text { Wor- } \\
\text { kers }\end{array}$ & & & $9 \%$ & $69 \%$ & $23 \%$ & 4.14 & 0.55 \\
\hline & $\begin{array}{l}\text { Non- } \\
\text {-wor- } \\
\text { kers }\end{array}$ & $6 \%$ & $34 \%$ & $51 \%$ & $9 \%$ & & 2.63 & 0.73 \\
\hline \multirow{2}{*}{$\begin{array}{l}\text { Generally, } \\
\text { I can achieve } \\
\text { outcomes that } \\
\text { are important } \\
\text { to me }\end{array}$} & $\begin{array}{l}\text { Wor- } \\
\text { kers }\end{array}$ & & $20 \%$ & $63 \%$ & $17 \%$ & & 3.97 & 0.62 \\
\hline & $\begin{array}{l}\text { Non- } \\
\text {-wor- } \\
\text { kers }\end{array}$ & $9 \%$ & $37 \%$ & $46 \%$ & $9 \%$ & & 2.54 & 0.78 \\
\hline \multirow{2}{*}{$\begin{array}{l}\text { I can succeed } \\
\text { at any ende- } \\
\text { avor when } \\
\text { I'm determi- } \\
\text { ned }\end{array}$} & $\begin{array}{l}\text { Wor- } \\
\text { kers }\end{array}$ & & & $14 \%$ & $60 \%$ & $26 \%$ & 4.11 & 0.63 \\
\hline & $\begin{array}{l}\text { Non- } \\
\text {-wor- } \\
\text { kers }\end{array}$ & $6 \%$ & $31 \%$ & $51 \%$ & $11 \%$ & & 2.63 & 0.76 \\
\hline \multirow{2}{*}{$\begin{array}{l}\text { I can success- } \\
\text { fully over- } \\
\text { come many } \\
\text { challenges }\end{array}$} & $\begin{array}{l}\text { Wor- } \\
\text { kers }\end{array}$ & & & $31 \%$ & $51 \%$ & $17 \%$ & 3.86 & 0.69 \\
\hline & $\begin{array}{l}\text { Non- } \\
\text {-wor- } \\
\text { kers }\end{array}$ & $6 \%$ & $63 \%$ & $23 \%$ & $9 \%$ & & 2.34 & 0.72 \\
\hline
\end{tabular}




\begin{tabular}{|c|c|c|c|c|c|c|c|c|}
\hline \multirow{2}{*}{$\begin{array}{l}\text { I am con- } \\
\text { fident that } \\
\text { I can perform } \\
\text { effectively } \\
\text { in most tasks }\end{array}$} & $\begin{array}{l}\text { Wor- } \\
\text { kers }\end{array}$ & & & $9 \%$ & $77 \%$ & $14 \%$ & 4.06 & 0.48 \\
\hline & $\begin{array}{c}\text { Non- } \\
\text {-wor- } \\
\text { kers }\end{array}$ & $9 \%$ & $31 \%$ & $57 \%$ & $3 \%$ & & 2.54 & 0.70 \\
\hline \multirow{2}{*}{$\begin{array}{l}\text { Compared } \\
\text { with other } \\
\text { people, I can } \\
\text { perform } \\
\text { effectively } \\
\text { in most tasks }\end{array}$} & $\begin{array}{l}\text { Wor- } \\
\text { kers }\end{array}$ & & & $49 \%$ & $29 \%$ & $23 \%$ & 3.74 & 0.82 \\
\hline & $\begin{array}{l}\text { Non- } \\
\text {-wor- } \\
\text { kers }\end{array}$ & $14 \%$ & $26 \%$ & $51 \%$ & $9 \%$ & & 2.54 & 0.85 \\
\hline \multirow{2}{*}{$\begin{array}{l}\text { I can perform } \\
\text { effectively } \\
\text { in difficult } \\
\text { situations }\end{array}$} & $\begin{array}{l}\text { Wor- } \\
\text { kers }\end{array}$ & & $3 \%$ & $34 \%$ & $27 \%$ & $6 \%$ & 3.66 & 0.64 \\
\hline & $\begin{array}{c}\text { Non- } \\
\text {-wor- } \\
\text { kers }\end{array}$ & $3 \%$ & $69 \%$ & $26 \%$ & $3 \%$ & & 2.29 & 0.57 \\
\hline \multirow{2}{*}{$\begin{array}{l}\text { General } \\
\text { self-efficacy } \\
\text { scale }\end{array}$} & $\begin{array}{l}\text { Wor- } \\
\text { kers }\end{array}$ & & & & & & 3.92 & 0.44 \\
\hline & $\begin{array}{l}\text { Non- } \\
\text {-wor- } \\
\text { kers }\end{array}$ & & & & & & 2.52 & 0.47 \\
\hline
\end{tabular}

Table 2 shows that among the students who work in the factory, the prevalent responses to the self-efficacy statements ranged between "to a large extent" (5 statements) and "to a moderate extent" (3 statements). In contrast, among students who did not work in the factory, the prevalent responses ranged between "to a moderate extent" ( 6 statements) and "to a small extent" (2 statements). In addition, it can be seen that among students who work in the factory, the frequency of "to a very large extent" ranged from zero to $26 \%$. While among students who do not work in the factory, this reply was not represented at all. Furthermore, looking at the averages shows that students that work in the factory tended to rate each of the statements, as well as the self-efficacy index, at a higher level, on average, than students who did not work in the factory. The picture that emerges is that students who work in the factory are characterized by higher self-efficacy than students who do not work in the factory.

The second hypothesis was that the sense of self-efficacy of those who work in the candle factory would be higher than those who do not work there. In order to examine this hypothesis, all the statements and the index were tested with t-tests for independent samples. These tests determined that students who work in the factory are characterized by a significantly higher 
level of self-efficacy than students who do not work in it. This finding was consistent with each of the statements (statement 1 : $\mathrm{t}(68)=7.83$, p <0.001; statement 2: $\mathrm{t}(63)=9.79, \mathrm{p}<0.001$; statement 3: $\mathrm{t}(65)=8.49, \mathrm{p}<0.001$; statement 4: $\mathrm{t}(68)=8.57, \mathrm{p}<0.001$; statement $5: \mathrm{t}(68)=8.94, \mathrm{p}<0.001$; statement $6: \mathrm{t}(60)=$ 10.54, $\mathrm{p}<0.001$; statement 7: $\mathrm{t}(68)=6.01, \mathrm{p}<0.001$; statement 8: $\mathrm{t}(68)=9.461$, $\mathrm{p}<0.001$, and overall self-efficacy index: $\mathrm{t}(68)=12.96, \mathrm{p}<0.001)$. The research hypothesis was fully confirmed.

\section{The contribution of working at the candle factory}

Sense of control

Table 3 presents the distribution of subjects' responses to statements regarding the extent of control, by group (workers/non-workersat the factory).

Table 3

Percentages, averages and standard deviation of subjects' responses to statements regarding sense of control, by group (workers/non-workers at the factory) $(\mathrm{N}=70)$

\begin{tabular}{|c|c|c|c|c|c|c|c|c|}
\hline $\begin{array}{l}\text { Statement/ } \\
\text { measure }\end{array}$ & Group & $\begin{array}{c}\text { To } \\
\text { a very } \\
\text { small } \\
\text { extent }\end{array}$ & $\begin{array}{c}\text { To } \\
\text { a small } \\
\text { extent }\end{array}$ & $\begin{array}{l}\text { To } \\
\text { a mo- } \\
\text { derate } \\
\text { extent }\end{array}$ & $\begin{array}{l}\text { To } \\
\text { a large } \\
\text { extent }\end{array}$ & $\begin{array}{l}\text { To } \\
\text { a very } \\
\text { large } \\
\text { extent }\end{array}$ & $\begin{array}{c}\text { Avera- } \\
\text { ge }\end{array}$ & $\begin{array}{l}\text { Stan- } \\
\text { dard } \\
\text { devia- } \\
\text { tion }\end{array}$ \\
\hline \multirow{2}{*}{$\begin{array}{l}\text { What happens } \\
\text { to me in the } \\
\text { future mostly } \\
\text { depends on me. }\end{array}$} & $\begin{array}{l}\text { Wor- } \\
\text { kers }\end{array}$ & & & $17 \%$ & $37 \%$ & $46 \%$ & 4.29 & 0.75 \\
\hline & $\begin{array}{l}\text { Non- } \\
\text {-wor- } \\
\text { kers }\end{array}$ & & $17 \%$ & $51 \%$ & $29 \%$ & $3 \%$ & 3.17 & 0.75 \\
\hline \multirow{2}{*}{$\begin{array}{l}\text { I can do just } \\
\text { about anything } \\
\text { I really set my } \\
\text { mind to do. }\end{array}$} & $\begin{array}{l}\text { Wor- } \\
\text { kers }\end{array}$ & & & $9 \%$ & $74 \%$ & $17 \%$ & 4.09 & 0.51 \\
\hline & $\begin{array}{l}\text { Non- } \\
\text {-wor- } \\
\text { kers }\end{array}$ & & $3 \%$ & $54 \%$ & $43 \%$ & & 3.40 & 0.55 \\
\hline \multirow{2}{*}{$\begin{array}{l}\text { I have many } \\
\text { ways to solve } \\
\text { an issue that } \\
\text { bothers me. }\end{array}$} & $\begin{array}{l}\text { Wor- } \\
\text { kers }\end{array}$ & & & $29 \%$ & $23 \%$ & $49 \%$ & 4.20 & 0.87 \\
\hline & $\begin{array}{l}\text { Non- } \\
\text {-wor- } \\
\text { kers }\end{array}$ & & & $51 \%$ & $43 \%$ & $6 \%$ & 3.54 & 0.61 \\
\hline
\end{tabular}




\begin{tabular}{|c|c|c|c|c|c|c|c|}
\hline \multirow{2}{*}{$\begin{array}{l}\text { I can change } \\
\text { only few of } \\
\text { the important } \\
\text { things in my life } \\
\text { (reverse state- } \\
\text { ment) }\end{array}$} & $\begin{array}{l}\text { Wor- } \\
\text { kers }\end{array}$ & $14 \%$ & $74 \%$ & $11 \%$ & & 1.97 & 0.51 \\
\hline & $\begin{array}{l}\text { Non- } \\
\text {-wor- } \\
\text { kers }\end{array}$ & $3 \%$ & $66 \%$ & $31 \%$ & & 2.29 & 0.52 \\
\hline \multirow{2}{*}{$\begin{array}{l}\text { Sometimes I feel } \\
\text { that I am being } \\
\text { pushed around } \\
\text { in life(reverse } \\
\text { statement) }\end{array}$} & $\begin{array}{l}\text { Wor- } \\
\text { kers }\end{array}$ & $14 \%$ & $74 \%$ & $11 \%$ & & 1.97 & 0.51 \\
\hline & $\begin{array}{l}\text { Non- } \\
\text {-wor- } \\
\text { kers }\end{array}$ & $3 \%$ & $66 \%$ & $31 \%$ & & 2.29 & 0.52 \\
\hline \multirow{2}{*}{$\begin{array}{l}\text { I often feel hel- } \\
\text { pless in dealing } \\
\text { with the pro- } \\
\text { blems of life(re- } \\
\text { verse statement) }\end{array}$} & $\begin{array}{l}\text { Wor- } \\
\text { kers }\end{array}$ & $14 \%$ & $74 \%$ & $11 \%$ & & 1.97 & 0.51 \\
\hline & $\begin{array}{l}\text { Non- } \\
\text {-wor- } \\
\text { kers }\end{array}$ & & $66 \%$ & $31 \%$ & $3 \%$ & 2.37 & 0.55 \\
\hline \multirow[t]{2}{*}{$\begin{array}{l}\text { Sense of control } \\
\text { scale }\end{array}$} & $\begin{array}{l}\text { Wor- } \\
\text { kers }\end{array}$ & & & & & 4.11 & 0.41 \\
\hline & $\begin{array}{l}\text { Non- } \\
\text {-wor- } \\
\text { kers }\end{array}$ & & & & & 3.53 & 0.32 \\
\hline
\end{tabular}

Table 3 shows that among students who work in the factory, the most common responses for the sense of control statements ranged between "to very large extent" (two statements) and "to a large extent" (one statement) and "to a moderate extent" for the three statements that are reverse worded. Among the students who do not work in the factory, the frequency of all the statements (even the reverse ones) was moderate.

Similarly, looking at the averages reveals that for the first three statements and for the sense of control index, the average ranking of students working in the factory is higher than the average ranking of students who do not work in the factory. Also, for the three reverse statements, the average ranking of students working in the factory is lower than the average ranking of students who do not work in the factory. The emerging picture is that in this sample, the sense of control of students working in the factory is higher than that of students who do not work in it.

The first part of our third hypothesis stated that the sense of control of students working in the candle factory would be higher than their non-working peers. In order to examine this hypothesis, t-tests for independent samples were conducted to test the difference in ranking of each of the statements 
regarding the sense of control, as well as for the sense of control index. These tests determined that students who work in the factory are characterized by a significantly higher sense of control. This finding is consistent across all statements (statement $1: \mathrm{t}(68)=6.23, \mathrm{p}<0.001$; statement 2 : $\mathrm{t}(67)=5.41$, $\mathrm{p}<0.001$; statement 3: $\mathrm{t}(68)=3.66, \mathrm{p}<0.001$; statement $4: \mathrm{t}(68)=-2.55, \mathrm{p}<0.05$; statement 5: $\mathrm{t}(68)=-2.55, \mathrm{p}<0.05$; statement $6: \mathrm{t}(68)=-3.15, \mathrm{p}<0.01)$ and in relation to the overall index of sense of control $(\mathrm{t}(68)=6.63, \mathrm{p}<0.001)$. Thus, the first part of the third hypothesis was fully confirmed.

\section{Contribution to the hope for the future}

The contribution of working in the factory to the sense of hope for the future was measured through a closed-ended questionnaire. Table 4 presents the distribution of responses to statements regarding the index of hope for the future, by group (workers/nonworkers).

Table 4 Percentages, averages and standard deviations of subjects' responses to statements regarding sense of hope for the future, by group (workers/non-workers at the factory) $(\mathrm{N}=70)$

\begin{tabular}{|c|c|c|c|c|c|c|c|c|}
\hline $\begin{array}{l}\text { Statement/ } \\
\text { measure }\end{array}$ & Group & $\begin{array}{c}\text { To } \\
\text { a very } \\
\text { small } \\
\text { extent }\end{array}$ & $\begin{array}{c}\text { To } \\
\text { a small } \\
\text { extent }\end{array}$ & $\begin{array}{l}\text { To } \\
\text { a mo- } \\
\text { derate } \\
\text { extent }\end{array}$ & $\begin{array}{c}\text { To } \\
\text { a large } \\
\text { extent }\end{array}$ & $\begin{array}{l}\text { To } \\
\text { a very } \\
\text { large } \\
\text { extent }\end{array}$ & $\begin{array}{l}\text { avera- } \\
\text { ge }\end{array}$ & $\begin{array}{l}\text { stan- } \\
\text { dard } \\
\text { devia- } \\
\text { tion }\end{array}$ \\
\hline \multirow{2}{*}{$\begin{array}{l}\text { 1. In the future } \\
\text { I will have } \\
\text { an interesting } \\
\text { profession } \\
\text { depends on } \\
\text { me. }\end{array}$} & Workers & & & $54 \%$ & $23 \%$ & $23 \%$ & 3.69 & 0.83 \\
\hline & $\begin{array}{l}\text { Non- } \\
\text {-workers }\end{array}$ & & $20 \%$ & $77 \%$ & $3 \%$ & & 2.83 & 0.45 \\
\hline \multirow{2}{*}{$\begin{array}{l}\text { 2. In the futu- } \\
\text { re, I will get } \\
\text { along with } \\
\text { my family. }\end{array}$} & Workers & & & $31 \%$ & $40 \%$ & $29 \%$ & 3.97 & 0.78 \\
\hline & $\begin{array}{l}\text { Non- } \\
\text {-workers }\end{array}$ & & $29 \%$ & $46 \%$ & $26 \%$ & & 2.97 & 0.75 \\
\hline \multirow{2}{*}{$\begin{array}{l}\text { 3. My economic } \\
\text { situation wo- } \\
\text { uld be very } \\
\text { good. }\end{array}$} & Workers & & & $46 \%$ & $43 \%$ & $11 \%$ & 3.66 & 0.68 \\
\hline & $\begin{array}{l}\text { Non- } \\
\text {-workers }\end{array}$ & & & $91 \%$ & $3 \%$ & $6 \%$ & 3.14 & 0.49 \\
\hline \multirow{2}{*}{$\begin{array}{l}\text { 4. I will have } \\
\text { a normal life }\end{array}$} & Workers & & & $23 \%$ & $40 \%$ & $37 \%$ & 4.14 & 0.77 \\
\hline & $\begin{array}{l}\text { Non- } \\
\text {-workers }\end{array}$ & & $14 \%$ & $74 \%$ & $11 \%$ & & 2.97 & 0.51 \\
\hline \multirow{2}{*}{$\begin{array}{l}\text { 5. The state of } \\
\text { mycountry } \\
\text { and the world } \\
\text { will be good }\end{array}$} & Workers & & & $57 \%$ & $37 \%$ & $6 \%$ & 3.49 & 0.61 \\
\hline & $\begin{array}{l}\text { Non- } \\
\text {-workers }\end{array}$ & & $29 \%$ & $57 \%$ & $14 \%$ & & 2.86 & 0.50 \\
\hline
\end{tabular}




\begin{tabular}{|c|c|c|c|c|c|c|c|}
\hline \multirow{2}{*}{$\begin{array}{l}\text { 6. In the future } \\
\text { I will have } \\
\text { close friends }\end{array}$} & Workers & & $51 \%$ & $43 \%$ & $6 \%$ & 3.54 & 0.61 \\
\hline & $\begin{array}{l}\text { Non- } \\
\text {-workers }\end{array}$ & $43 \%$ & $57 \%$ & & & 2.57 & 0.50 \\
\hline \multirow{2}{*}{$\begin{array}{l}\text { 7. I will have } \\
\text { a job in the } \\
\text { future }\end{array}$} & Workers & & $31 \%$ & $40 \%$ & $29 \%$ & 3.97 & 0.78 \\
\hline & $\begin{array}{l}\text { Non- } \\
\text {-workers }\end{array}$ & & $83 \%$ & $17 \%$ & $74 \%$ & 3.20 & 0.47 \\
\hline \multirow{2}{*}{$\begin{array}{l}\text { 8. I will continue } \\
\text { my studies in } \\
\text { the future }\end{array}$} & Workers & & $69 \%$ & $26 \%$ & $6 \%$ & 3.37 & 0.60 \\
\hline & $\begin{array}{l}\text { Non- } \\
\text {-workers }\end{array}$ & $9 \%$ & $17 \%$ & $74 \%$ & & 2.66 & 0.64 \\
\hline \multirow{2}{*}{$\begin{array}{l}\text { 9. In the future } \\
\text { I will do the } \\
\text { things I like to } \\
\text { do (my hob- } \\
\text { bies) }\end{array}$} & Workers & & $11 \%$ & $43 \%$ & $34 \%$ & 3.46 & 0.85 \\
\hline & $\begin{array}{l}\text { Non- } \\
\text {-workers }\end{array}$ & $49 \%$ & $43 \%$ & $9 \%$ & & 2.60 & 0.65 \\
\hline \multirow[t]{2}{*}{ Hope scale } & Workers & & & & & 3.73 & 0.52 \\
\hline & $\begin{array}{l}\text { Non- } \\
\text {-workers }\end{array}$ & & & & & 2.90 & 0.23 \\
\hline
\end{tabular}

Looking at the prevalent answers in Table 4, one can see that all students expressed a medium to high degree of hope for their future. In addition, students who work in the factory expressed a medium degree of hope about acquiring a profession in the future, their economic situation, the situation of their country and the world, regarding having close friends and future studies, and a great hope of getting along with their family, living a normal life, having a job and exercising their hobbies (Determined by the prevalent answer). In contrast, students who do not work in the school factory expressed a medium degree of hope in most areas: acquiring a profession in the future, regarding their job, getting along with their family, their economic situation, living a normal life, the situation of their country and the world, and having friends. Furthermore, they expressed a great deal of hope for future studies and little hope for exercising their hobbies.

Reviewing the averages reveals that the four areas, in which the students working in the factory were hopeful about (in descending order) are: living a normal life, having a job in the future, getting along with their family and having a profession. Similarly, the four areas in which the students who do not work in the plant were hopeful about (in descending order) are: having a job, a good economic situation, a normal life, and getting along with their family. In addition, the average ranking of students working in the factory ranges from 3.37 to 4.14 , i.e., there is a high degree of hope. In contrast, the average ranking of students who do not work in the factory ranges from 2.57 to 3.20 , i.e., only a medium level of hope. Also, it can be seen that for each 
area, as well as for the general index of hopes for the future, the average ranking of students working in the factory is exceeding the average ranking of students who do not work in the factory.

The second part of hypothesis 3 was that student who work in the candle factory will have higher hopes for the future than their peers who do not work there. In order to test the hypothesis regarding future hopes, t-tests were conducted for independent samples to examine the difference between the two groups in the ranking of each of the statements regarding future hopes and the whole index. These tests determined that students who work at the factory are more hopeful about their future than students who do not work in the factory. This finding was found to be consistent with each of the domains (profession: $(\mathrm{t})(52)=5.35, \mathrm{p}<0.001$; family: $\mathrm{t}(68)=5.46, \mathrm{p}<0.001$; economic situation: $\mathrm{t}(62)=3.61, \mathrm{p}<0.001$; normal life: $\mathrm{t}(59)=7.49, \mathrm{p}<0.001$; situation in the country and in the world: $\mathrm{t}(68)=4.17, \mathrm{p}<0.001$; close friends: $\mathrm{t}(68)=7.27$, $\mathrm{p}<0.001$; job: $\mathrm{t}(56)=4.98, \mathrm{p}<0.001$; future studies: $\mathrm{t}(68)=4.83, \mathrm{p}<0.001$; hobbies: $\mathrm{t}(68)=4.73, \mathrm{p}<0.001)$ and in relation to the overall index of hopes for the future $(\mathrm{t}(47)=8.53, \mathrm{p}<0.001)$. The third hypothesis was fully confirmed.

\section{Summary, discussion and practical conclusions}

Summary and discussion

The current study concerned school intervention program for students coming from a weak background. The intervention is a program that combines employment and learning and aims to attract young people to study and provide them with vocational skills. One of the characteristics of the target population is difficulty in perseverance, thus the proposed program is intended to promote academic perseverance and thereby reduce dropout rates. In addition, the school strives to provide youth at risk with a variety of personal and interpersonal skills that are important both for studies and for labor world.

The research literature on dropout focuses on two foci: the student and the school. Most studies focus on the student. These studies seek to identify students' characteristics (demographics, socioeconomic status, psychological aspect, and experience in educational institutions) which drive dropping out of school. A relatively small number of studies deal with the other focal point, the school.

The current study discusses the dropout phenomenon at the school level. In this context, the study examined whether, despite the characteristics of students that indicated a high probability for dropping out of school, the school could keep these students and prevent them from dropping out of school. In this context, the first hypothesis suggested that the work in the candle factory would provide students from a weak background with the opportunity to learn in a method adapted to their level and needs, and would constitute 
a "safety net" which prevents latent dropout among these students, when such dropout is expressed in tardiness, absenteeism and involvement in violent events. The findings showed that combining learning with work in the candle factory promoted attendance and reduced violent behavior in school. In other words, it reduced the latent dropout from school.

As noted, irregular attendance and violent behavior are among the aspects that characterize latent dropout. Irregular attendance and academic achievements are measurable variables in school reality and therefore are the first "warning signs" of latent dropout.

Various school factors affect students' attendance and perseverance. For these adolescents, school is an environment that may add to their resilience or increase their risk. ${ }^{4}$ Therefore, an optimal climate, in which, alongside encouragement to increase scholastic achievements, there is also attention to the student emotional and social needs, creates the conditions for effective learning that may compensate for the limiting conditions in the youngster natural environment. Among the eminent characteristics for creating an optimal climate is the communication quality between the youth and their teachers. The work in the candle factory was based on a personal and supportive connection with the group of employees, high expectations from the students and belief in their abilities. According to Cohen-Navot et-al (2001), ${ }^{5}$ teachers who convey high expectations from their students, motivate them to continue and persist in their studies.

School factors mentioned above include curricula that are not relevant to the learners. ${ }^{6}$ A school program that is compatible with students' learning skills and their future needs prevents dropout among students at risk. ${ }^{7}$ The success of the factory in reducing latent dropout is related, to a large extent, to the existence of activities and workshops that are appropriate for the students' needs and to the willingness of the school to keep these students, even when they fail in their studies.

In the intervention program, students received, alongside their academic studies, also vocational training. Pinquart and colleagues $(2003)^{8}$ found that the integration of intellectual-academic core subjects with vocational training courses within the curriculum, emphasizes the relevance of education to student success in their adult life, and as a result helps to reduce dropout from the education system.

${ }^{4}$ C. Lahav, Putting the phenomenon of Youth at risk in Perspective, http:/ / noar.education.gov. il, 2002, [Retrieved: 14.04.2012], p. 1-2.

${ }_{5}$ M. Cohen-Navot, S. Ellenbogen-Frankovits, T. Reinfeld, Overt and Covert, p. 16-17.

${ }^{6}$ Ibidem.

7 Ibidem.

8 M. Pinquart, L. Juang, R. Silbereisen, Self-Efficacy and successful school to work transition: A longitudinal study, Journal of Vocational Behavior, 2003, (63), p. 330. 
The candle factory is mainly a workplace. Workplace can become a fertile ground for an academic learning process if one can view the workplace as a learning environment, or it can help inspire the desire to learn in order to professionalize or advance at work. ${ }^{9}$ According to this, the students seethe factory as a learning place, in which they could advance at work and therefore continued attend school.

Among the personal factors, one can find self-perception as an influencing factor on learning perseverance. Shemesh $(1987)^{10}$ argued that the greater the sense of self-efficacy of students is, the greater is their level of adaptation to school, an adaptation that is reflected in positive attitudes towards school. Positive attitudes increase the likelihood for perseverance. ${ }^{11}$

An important finding of this study is the increase in the sense of self-efficacy of students working in the factory. This personal resource might explain the decrease in dropout rate in the current study.

Reducing school dropout is a major challenge of the Israeli education system, as is in many other countries in the Western world. This policy strives to achieve equal access to secondary and higher education among all social groups. It is an important policy, but in itself is not enough. It is very important to ensure that students will remain in the system and derive the best of the educational process. Many students find it difficult to meet the requirements of the system for academic or cultural reasons. Keeping them in the system requires coping with these difficulties in order to strengthen their connection to school and prevent their exposure to school dropout of any kind.

\section{In addition to promoting perseverance in learning,the school factory has also succeeded in reducing violent behaviors}

Gilboa (2004) $)^{12}$ argues that students who succeed in accepting school's normative framework and values, succeed in surviving within the system, while those who do not accept these values do not survive in it and therefore demonstrate violence towards it.

\footnotetext{
${ }_{9}$ C. Stasz, D. Stern, Work Based Learning for Students in High Schools and Community Colleges, Center Point - Collected Works, 1998, p. 4-6.

${ }^{10} \mathrm{I}$. Shemesh, Evaluation of an intervention program to prevent dropout, regarding students' level of adaptation and the types of high schools in which they were placed, Israel 1987, p. 38-40.

${ }_{11}$ V. Sasoon-Peretz, An Examination of Variables: Self-image, Scholastic Achievements, Social Orientation, and Focus of Control in a Unique Framework for Disengaged Youth, Israel 1998, p. 45-48.

${ }_{12}$ E. Gilboa, Society in a violent society, Journeys towards education in society and culture, 2004, p. 15-18.
} 
This assertion may serve as a good explanation for the reduction in violent behaviors among students working in the factory. The working students were attracted to the school and continued their studies because they see the program as an appropriate intervention that suits their needs and educational level. The framework is acceptable to them, they feel belonging to this place and therefore there is no demonstration of violence towards it.

Another explanation for the reduction in the extent of violence among the factory workers is related to achievements and feelings of detachment from school. Harel and Laufer (2003) ${ }^{13}$ found that school variables, especially the sense of detachment from the school, lack of achievements, and perception of high level of violence in school environment, are related to bullying, fighting and carrying weapons. In their opinion, bored students, who tend to run away from school, who have low achievements and that claim that their school has a high level of violence, are more likely to be involved in bullying and fighting. Working at the candle factory gave these students a sense of success. They can boast about their achievements at the factory, they are no longer the under-achieving, useless and unvalued students of their class. Their achievements have led them to substitute their sense of detachment for sense of belonging to the supportive climate and to an environment that is fun to learn in and to being active and productive.

Goldstin (1994) $)^{14}$ presents a number of explanations for the way in which young people from low socio-economic status end up in behaving violently. According to his view, there is a tension between the economic and social aspirations of these youth and the opportunities and possibilities they are given. Another explanation is the adaptation of their behavior to labels that tag them as marginal youth and the antagonism of weaker groups towards the higher society that wants to dominate them.

Up until their participation in the program, these students did not attend school because they did not find any relevance in learning. The curriculum did not suit them. As a result, they spent most of their time on the streets and when they did attend school, they found themselves involved in violent incidents. The program offered them learning in a domain that meets their needs, abilities and aspirations, and provided them with a good reason to get up in the morning and attend school. Their self-image and motivation to succeed grew accordingly. The program gave them the opportunity to become useful and contribute to themselves, their families and the society in general. The change they experienced through the program distanced them from their sense of marginality and as a result from involvement in violent incidents.

${ }_{13}$ Y. Harel, A. Laufer, Correlation between school perception and pupil involvement in bullying, physical fights and weapon carrying, Megamot, 2003, (42)4, p. 40-43.

${ }^{14}$ A.P. Goldstien, Delinquent gangs, [In:] Aggressive behavior: Current perspectives, Ed. L.R. Huesmann, New York 1994, p. 260-262. 
The reduction in tardiness and absenteeism as well as in violent behaviors indicates that the candle factory did contribute to perseverance and reduced the extent of latent dropout, which might become an overt dropout after some time.

The second hypothesis was that workers' sense of self-efficacy would be higher than that of their schoolmates who do not work at the factory. This hypothesis is based on studies that found that high self-efficacy is related to academic success in particular and in learning in general. ${ }^{15}$ In the current study, significant differences were found in the level of self-efficacy of the subjects in both groups.

The first explanation for the significant difference in the sense of self-efficacy that tend in favor of the "workers" group can be attributed to the successful experiences they had in the factory. This explanation is in line with Bandura's (1986) ${ }^{16}$ assertion that self-efficacy is shaped and built by the process of learning, in which the individual is given information about his or her self-efficacy. The most significant source of information in this process is an experience in successful performance and acquisition of experiences of success.

Another explanation for the significant difference in the sense of self-efficacy between the workers and the non-workers is related, to a large extent, to the challenges posed to the workers in the factory. It can be argued that the factory presented to its students with challenges that were tailored to their needs and abilities, whether in the design and construction of the product packaging, the mixing of colors, the ways of marketing the products or in the encounter with tourists and speaking in English in order to persuade them to buy the product and provide them with the necessary information about the offered item. This explanation is in line with Mart's (2011) $)^{17}$ suggestion that in order to develop a high sense of self-efficacy among the learners, it is necessary to provide them with appropriate challenges according to their needs and level.

The teaching staff, which is in charge of planning and implementing the program and who is in personal contact with the students working in the factory, has a significant in increasing the sense of self-efficacy among the workers in the factory. According to Bandura (1986), ${ }^{18}$ another source for increasing the self-efficacy is verbal persuasion. The meaning is the convincement of other people in the learner's ability to perform a task successfully.

$15 \mathrm{~S}$. Katz, Self-efficacy - the best predictive motivational component of academic performance, Shaanan College Annual, 2002, (8), p. 168-1173.

16 A. Bandura, Social foundations of thought and action, New York 1986, p. 50-52.

17 C. Mart, How to sustain students motivation in a learning environment, http://www.eric. ed.gov/contentdelivery/servlet/ERICServlet?accno=ED519165, November 10. 2011.

18 A. Bandura, Social foundations, p. 52-53. 
The teachers, who worked with the students, believed in their abilities and conveyed them their high expectations of them. They even encouraged them to make the most out of their efforts and creativity, thereby increased their sense of efficacy.

According to Vallerand et al. (1997), ${ }^{19}$ the boy's perception of his abilities and own expectations greatly influences the decision to leave the school setting. This finding is in line with the findings of the first hypothesis, which claims that working at the candle factory would prevent the dropout of students and promote perseverance in learning. In addition, according to Pinquart et al. (2000), ${ }^{20}$ self-efficacy has an effect on the motivation to learn. One can assume that following the finding that the workers improved their sense of self-efficacy, that their motivation to learn will also increase and so does their achievements in many aspects of life.

The third hypothesis was that both workers' sense of control and their sense of hope for the future would be higher than that of their schoolmates who do not work in the factory.

\section{Sense of control}

In the present study, it was found that the sense of control expressed by subjects in the workers group was significantly higher than that of the non-workers group.

As mentioned earlier, the students who worked in the factory had many successful experiences during their work in there. Success was found to be one of the key factors in developing a sense of control among these youth. ${ }^{21}$

It was also found ${ }^{22}$ that the sense of control assists in effective activity; On the other hand, sense of helplessness decreases the motivation to cope with problems and challenges. Therefore, it can be assumed that the motivation to continue to learn and work will also increase among the workers. Studies conducted in schools ${ }^{23}$ showed that students' sense of control decreases the risk of dropping out. This finding is consistent with the finding of our first hypothesis, which has showed increase in perseverance.

\footnotetext{
${ }^{19}$ R.J. Vallerand, M.S. Fortier, F. Guary, Self-Determination and Persistence in a Real-Life Setting: Toward a Motivational Model of High School Dropout, Journal of Personality and Social Psychology, 1997, 72, p. 1169-1171.

${ }_{20}$ M. Pinquart, L. Juang, R. Silbereisen, Self-Efficacy and successful school to work transition, p. 334-336.

${ }^{21}$ E. Ross, C.A. Beckett Broh, The Roles of Self-Esteem and the Sense of Personal Control in the Academic Achievement Process, Sociology of Education, 2000, 73(4), p. 273-276.

${ }^{22}$ Ibidem.

${ }^{23}$ Ibidem, p. 277.
} 
Given the significance of the difference in the self-efficacy index between these groups, the question is to whether this should be considered as an essential and lengthy change indicating a change in the boys' personality, or whether it is a random outcome of a one-time feeling of success in a particular program? The significance of the sense of control index may provide an answer to this question.

Number of researchers, such as Kirsch (1985), ${ }^{24}$ have argued that self-efficacy is greatly influenced by the "expectation of success in life", as was described by Bandura (1977), ${ }^{25}$ and the locus of control (internal-external). Thus, only success, or failure, which are perceived as stemming from internal factors, will be the ones that will influence the perception of self-efficacy. ${ }^{26}$ Given that, attributing the success to a random, one-time, and insignificant event is not probable to result in a fundamental change in perception of self-efficacy. ${ }^{27}$ A high efficacy perception is, therefore, a result of an expectation of personal success and its attribution to internal factors. On the other hand, a low efficacy perception is the result of attributing personal failure to internal factors. This principle contradicts another argument, which states that the boys demonstrated an improvement in their perception of self-efficacy due to the fact that the program has easy or flexible requirements than what was required of them in other settings. According to this principle, success in challenges, due to internal control loci, is expected to increase the perception of self-efficacy and also the expectation for success in the future. Thus, those who have a high perception of efficacy tend to set for themselves higher bars for success and growing willingness to meet personal challenges ${ }^{28}$ It is therefore unlikely that the perception of self-efficacy will increase due to a decrease in the demands and challenges faced by the participants in the intervention program.

\section{Difference in the sense of hope for the future}

The workers group reported about hopes for the future significantly more than the non-workers group. The construct of hope is defined by Snyder $(2002)^{29}$ as goal-oriented thinking, through which people outline paths and

${ }^{24}$ I. Kirsch, Self-efficacy and expectancy: Old wine with new labels, J Pers Soc Psychol, 1985, 49, p. 827-828.

25 A. Bandura, Self-efficacy: Toward a unifying theory of behavioral change, Psychological Review, 1977, 84, p. 209.

${ }^{26}$ B. Weiner, An attributional theory of achievement motivation and emotion, Psychological Review, 1985, (92), p. 548-550.

${ }_{27}$ M. Sherer, J. Maddux, The Self-Efficacy Scale: Construction and validation, Psychological Reports, 1982, (51), p. 666-669.

28 A. Bandura, Self-efficacy: Toward a unifying theory, p. 211.

${ }^{29}$ C.R. Snyder, Hope theory: Rainbows in the mind, Psychological Inquiry 2005, (13), p. 254. 
directions towards achieving that goal and they believe in their ability to persist in this way until it is achieved. It can assumed, therefore, that the workers in the factory will have a strong belief in their ability to influence their future and advance towards it. They will have clear plans for the future and they will be able to accomplish them.

The target population of youth working in the factory is characterized by low self-image, low self-esteem and concrete thinking. The behavioral expression of these characteristics is planning for the immediate and short term only, expressions of inability to commit and plan for the long-term, and a lack of basic trust in their ability. ${ }^{30}$ According to Snyder (2002), ${ }^{31}$ feelings of hope involve elements of expectation, as well as cognitive components and deductive thinking, aimed at executing new ideas and solutions. Since the workers group had a high sense of hope for the future, I believe that their level of commitment to the future and for implementing these plans will also increase.

Having hopes for the future requires the individual to set goals, to plan how they can be achieved and to use their imagination, creativity, flexible thinking, and their ability to take risks. ${ }^{32}$ The students working in the factory reported on a very high level of hope in the field of returning back to school and acquiring a profession and a job in the future. This high hope, in turn, will help them to plan these two important areas in the future and even realize it.

An explanation for the difference in the extent of the hope for the future between the two groups is related to the strong belief of the teaching staff in the students working in the factory. This explanation is consistent with Snyder's assertion, ${ }^{33}$ that in order to develop and encourage the development of hope within children and adolescents, there is a need for adults who believe in them, increase their positive strengths and help them to improve their skills that are related to the trait of hope.

Snyder (2005) ${ }^{34}$ argues that high levels of hope were found to be associated with good achievements, good psychological adjustment, and satisfaction from life. This argument provides another explanation for the high level of hope found among the workers and is related to their successes and achievements in the factory. These students realized their abilities through their work in the factory, they explained the intervention program to various organizations, participated in conferences, and presented the program to school

${ }^{30}$ C. Lahav, Preperaing the youth for the future labor world - whos responsibility it is? Disengagement to Integration, 2007, (14), p. 42-43.

31 C.R. Snyder, Hope theory, p. 255-256.

${ }^{32}$ Ibidem, p. 257.

33 Ibidem.

34 Ibidem, p. 249-275. 
staff. They also explained the nature of their work and the change they had experienced to stakeholders in the Ministry of Education. The above and their own satisfaction empowered them and made them proud of themselves and being satisfactory with their lives in society.

The study also found, that all subjects (in both groups) showed a great hope of having a job in the future. In the research literature, there is a large discussion on the place of work in human life. The following review explains the high hope all participants expressed regarding future jobs. Harpaz $(1990)^{35}$ divides the significance of work for the individual into three dimensions: the first is the instrumental dimension - people work on in order to ensure their livelihood and provide for themselves with material needs. The second dimension is a human need - a human-being is characterized by the need to exert effort, learn, develop, achieve and influence his environment. The third dimension is the need for meaning. The work creates a meaning to the person's life; It shapes his identity, creates stability and continuity in his life, and provides him a sense of being an essence for the society.

According to Harpaz, ${ }^{36}$ since status and rewards in the society are determined according to the position of the person in the labor market, very few people can afford themselves not to work. In his opinion, the society is stigmatic towards people who do not work, and they are usually end up being marginalized. Gal (2004) $)^{37}$ argues that in many human societies, work is perceived as a civic duty and lack of work is a serious social and personal problem. Because the labor world occupies such a central place in our adult life, this is where most of our efforts are directed to when entering the adult world. ${ }^{38}$

The research findings raise many questions about the nature of the current intervention program and the impact it has on the students participating in it. In fact, the study found significant differences in all variables examined, between the group of workers and the group of non-worker. It can be assumed that the workers receive from the program an empowerment, which is beyond their studies, and it is probably influencing other aspects of their lives.

The findings of this study are consistent with the literature. Based on the literature review it is speculated that there would be differences between the groups in all the variables. The literature stresses the great contribution, of programs that combine learning and work, for the students: increasing their

\footnotetext{
${ }^{35}$ I. Harpaz, The meaning of work in Israel - Its nature and consequences, New York 1990, p. 39-40.

${ }^{36}$ Ibidem.

${ }^{37}$ J. Gal, Social Security in Israel, Jerusalem 2004, p. 33-35.

${ }^{38}$ C. Lahav, Processes and transformations among ultra-Orthodox and religious youth at risk, who
} is treated by youth promotion units in Israel, Disengagement to Integration, 2005, (13), p. 51. 
self-confidence, strengthening their cognition thinking, development of social skills, increased independence, and prevention of dropping out of school. ${ }^{39}$

By analyzing the findings and being familiar with the program, we can learn that an effective intervention program is a one in which the teachers are the first target audience - through them students can be reached. An increasing and cumulative body of data indicates that the imposition of a curriculum by external bodies in a "top to bottom" approach, whereby a teacher is expected to execute and implement developers' philosophy, views, and goals is ineffective in introducing educational innovations related to school curricula. ${ }^{40}$

Teachers are the ones who translate the great ideas into the language of reality in school. Teachers who are leaders go out of their way in search of innovations and exciting programs for the benefit of their students and for themselves. The time has come to recognize this and its consequences. Teachers should be given the status of experts in their fields. Expertise means professional judgment and participation in decision-making. Trust is known to encourage people to be trustworthy. Schools and the local and national educational systems should act as frameworks that enable teachers to think, consultation with teachers, and in particular, the preservation and the use of teachers' knowledge. There is an urgent need to develop mechanisms and spaces that allow for broad participation of teachers in decision-making concerning teaching and education. Those who dare to follow this path will be surprised to find teachers having a great deal of experience and a unique perspective, teachers who have the key to solve most of the pressing problems of our education system.

\section{BIBLIOGRAPHY}

Bandura A., Self-efficacy: Toward a unifying theory of behavioral change, Psychological Review, 1977, 84.

Bandura A., Social foundations of thought and action, Englewood Cliffs, NJ: Prentice-Hall 1986.

Bandura A., Self Efficacy in changing societies, Cambridge University Press 1995.

Brand M., Exhausted from educational reform, http:/ / www.jstor.org.ezproxy.stthomas.edu/ stable/40319322 Bulletin of the Council for Research in Music Education, 2009, (180).

CBS, Society in Israel, Statistical Annual - Report No. 3, Israel 2015.

${ }^{39}$ Hayward, Tallmadge, Based on evaluation of dropout prevention and reentry projects in vocational education funded under the Cooperative Demonstration Program (CDP) of the Carl D. Perkins Vocational Education Act, 1995, p. 18-19.

${ }^{40}$ M. Brand, Exhausted from educational reform, http://www.jstor.org.ezproxy.stthomas.edu/ stable/40319322 Bulletin of the Council for Research in Music Education, 2009, (180), p. 89-91. 
Cohen-Navot M., Ellenbogen-Frankovits S., Reinfeld T., Overt and Covert dropout among youth, Knesset Research and Information Center, JDC - Brookdale Institute 2001.

Gal J., Social Security in Israel, Magnes Press, Jerusalem 2004. (In Hebrew)

Gilboa E., Society in a violent society, Journeys towards education in society and culture, 2004, (In Hebrew).

Goldstien A.P., Delinquent gangs, [In:] Aggressive behavior: Current perspectives, Ed. L.R. Huesmann, Plenum Press, New York 1994.

Harel Y., Laufer A., Correlation between school perception and pupil involvement in bullying, physical fights and weapon carrying, Megamot, 2003, (42)4. (In Hebrew)

Harpaz I., The meaning of work in Israel - Its nature and consequences, Praeger, New York 1990.

Hayward, Tallmadge, Based on evaluation of dropout prevention and reentry projects in vocational education funded under the Cooperative Demonstration Program (CDP) of the Carl D. Perkins Vocational Education Act, 1995.

Katz S., Self-efficacy - the best predictive motivational component of academic performance, Shaanan College Annual, 2002, (8). (In Hebrew)

Kirsch I., Self-efficacy and expectancy: Old wine with new labels, J Pers Soc Psychol, 1985, 49.

Kotzer J., Margalit M., Perception of competence: Risk and protective predictors following an e-self-advocacy intervention for adolescents with learning disabilities, European Journal of Special Needs Education, 2007, 22(4).

Lahav C., Preperaing the youth for the future labor world - whos responsibility it is? Disengagement to Integration, 2007, (14).

Lahav C., Processes and transformations among ultra-Orthodox and religious youth at risk, who is treated by youth promotion units in Israel, Disengagement to Integration, 2005, (13). (In Hebrew)

Lahav C., Putting the phenomenon of Youth at risk in Perspective, http://noar.education.gov. il, 2002, [Retrieved: 14.04.2012].

Lauterbach W.L., Alienation, anomie and dropout, Dissertation abstracts, A. Arbor, Michigan 1967.

Levitt R., Freedom and empowerment: A transformative pedagogy of educational reform, Educational Studies, 2008, 44(1) doi: 10.1080/00131940802225085.

Mart C., How to sustain students motivation in a learning environment, http:/ / www.eric.ed. gov/contentdelivery/servlet/ERICServlet?accno=ED519165, November 10. 2011.

National Academy Foundation, A Guide to work-based learning: A continuum of activities and experiences, New York 2012.

Pinquart M., Juang L., Silbereisen R., Self-Efficacy and successful school to work transition: A longitudinal study, Journal of Vocational Behavior, 2003, (63).

Ross E., Beckett Broh C.A., The Roles of Self-Esteem and the Sense of Personal Control in the Academic Achievement Process, Sociology of Education, 2000, 73(4).

Sasoon-Peretz V., An Examination of Variables: Self-image, Scholastic Achievements, Social Orientation, and Focus of Control in a Unique Framework for Disengaged Youth, Mifne, Masters' thesis presented to Bar-Ilan University, Ramat-Gan, Israel 1998.

Shemesh I., Evaluation of an intervention program to prevent dropout, regarding students' level of adaptation and the types of high schools in which they were placed, Masters' thesis presented to Tel-Aviv University, School of Social Work, Ramat-Aviv, Israel 1987.

Sherbinko T., Examining the factors that promote long-term change in elementary teachers' instructional practices: Sustaining formative assessment reform, Doctoral dissertation, Available from ProQuest Dissertations and Theses database 2011, (UMI No.11430069).

Sherer M., Maddux J., The Self-Efficacy Scale: Construction and validation, Psychological Reports, 1982, (51). 
Snyder C.R., The psychology of hope: You can get there from here, [In:] Handbook of Hope Theory, Measures and Applications, Ed. C.R. Snyder, Academic Press, San Diego 2000.

Snyder C.R., Hope theory: Rainbows in the mind, Psychological Inquiry 2005, (13).

Stasz C., Stern D., Work Based Learning for Students in High Schools and Community Colleges, Center Point - Collected Works, 1998.

Tallmadge H., Based on evaluation of dropout prevention and reentry projects in vocational education funded under the Cooperative Demonstration Program (CDP) of the Carl D. Perkins Vocational Education Act, 1995.

Vallerand R.J., Fortier M.S., Guary F., Self-Determination and Persistence in a Real-Life Setting: Toward a Motivational Model of High School Dropout, Journal of Personality and Social Psychology, 1997, 72.

Weiner B., An attributional theory of achievement motivation and emotion, Psychological Review, 1985, (92). 